\author{
Sustinere \\ Journal of Environment and Sustainability \\ Volume 4 Number 3 (2020) 189-204 \\ Print ISSN: 2549-1245 Online ISSN: 2549-1253 \\ Website: https://sustinerejes.com E-mail: sustinere.jes@iain-surakarta.ac.id
}

\title{
RESEARCH PAPER \\ The impact of Cirebon coal-fired power plants on water quality in Mundu Bay, Cirebon Regency
}

\author{
Millary Agung Widiawaty ${ }^{1}$, Nurhanifah ${ }^{1}$, Arif Ismail ${ }^{1 *}$, Moh. Dede ${ }^{2}$ \\ ${ }^{1}$ Departement of Geography Education, FPIPS, Universitas Pendidikan Indonesia, Indonesia \\ ${ }^{2}$ Master Program on Environmental Science, Postgraduate School, Universitas Padjadjaran, Indonesia
}

Article history:

Received 22 June 2020 | Accepted 5 October 2020 | Available online 31 December 2020

\begin{abstract}
The presence of Cirebon coal-fired power plant I and II caused negative effects to coastal morphology and the quality of marine waters. This also have negative impacts to the fisherman around that sea. This study aims to examine the impact of the Cirebon coal-fired power plant on the water quality of Mundu Bay, Cirebon Regency. Water quality is determined based on total suspended solids (TSS), sea surface temperatures (SST), chlorophyll-A, and salinity in the range $1999-2019$. Data collection was carried out using satellite imagery of Landsat-5 TM, Landsat- 7 ETM+, and Landsat-8 OLI verified with in-situ field measurements, Sentinel-2 A MSI, and MODIS Aqua imageries. Changes in water quality due to the infrastructure of the two power plants are known through the Mann-Whitney UTest and Spearman's correlation analysis. This research shows that two Cirebon coal-fired power plant has a significant effect on changes in the quality of Mundu Bay waters. Changes in water quality are shown by a significant increase in TSS concentrations and SST values accompanied by a decrease in chlorophyll-A levels and salinity levels. Changes in the quality of these waters also disrupt marine biota habitat and cause fishermen in around are difficult to get the ideal catchment yield.
\end{abstract}

Keywords: Cirebon steam power plant; Mundu bay; remote sensing; water quality

\section{Introduction}

Development is process-oriented towards fulfilling the needs of human life and livelihood on Earth. Although development is essentially anthropocentric, it demands the preservation of environmental carrying capacity to prevent many disasters and destructions (Abdullah, 2017). In energy sector, the development to provide adequate energy have multiplier capabilities and can drive diverse sectors (Aissa \& Hartono, 2016). The efficiency of energy changes can be viewed from the entropy such as electrical power output and heat released into the environment, along with the various wastes it produces (Levine \& Kendall, 2006; Xu et al., 2020).

Indonesia has abundant natural resources for developing energy such as wind, sunlight, geothermal, and ocean current. However, it still experiencing problems in fulfilling electricity, whereas the Indonesian government has targets to realize an electrification ratio of up to 99.9

${ }^{*}$ Corresponding author. E-mail: arifismail@upi.edu DOI: https://doi.org/10.22515/sustinere.jes.v4i3.114 
percent by 2020 (Legino et al., 2019). In order to accelerate the fulfillment of electricity for household and industrial needs, the Government launched a 35,000 $\mathrm{mW}$ power plant development program by 2028 - after withdrawing from its previous target in 2019 (Untsa, 2017). The goal of fulfilling electrical energy in a short time causes the use of non-renewable resources, especially coal-fired power plant, inevitable (Cahyadi, 2011; Yang et al., 2019). This is evidenced by the construction of coal steam power plant projects in several regions in Java in order to fulfill the increasing electrical energy needs.

The coal-fired power plant presences are an effort to create market share for the domestic mining industry, considering that Indonesia is main producer of coal commodities in the world (Hudaya \& Madiutomo, 2019; Rosyid \& Adachi, 2016). In addition, coal-fired power plants can be built more easily and placed closer to users after going through various suitability studies, thus production costs are relatively cheaper. Pragmatically, the construction of a coal-fired power plant is a surefire solution to fulfill the electrical energy needs. Even though when examined carefully, the coal-fired power plant operation in the long term also contributes to environmental impacts such as decreasing the quality of water, air and land which will have implications for socio-economic conditions (Dede et al., 2020; Ha-duong et al., 2016; NRDC, 2014). Operational cases of the coal-fired power plant which has helped to change the quality of the environment and socio-economy around it are Cirebon coal-fired power plant. The power plant that was built in the early 2000s known as the PLTU Cirebon I was able to provide $660 \mathrm{~mW}$ of energy to support the fulfillment of industrial and household needs in the western region of Java (Prima, 2018).

Although PLTU Cirebon claimed to be a pioneer of clean coal technology, the construction and operation of the coal-fired power plants in a coastal area will change the coastal landscape, air, and water quality (Choi et al., 2012; Kumar et al., 2013). It has implications for decreasing catches, as well as causing fishermen to decrease in profit margins due to the greater cost to reach the ideal waters for fishing. This problem also caused protests from the surrounding community towards PLTU Cirebon I, although the results remained nil and continued with the presence of second coal-fired power plant (PLTU Cirebon II). At present, Mundu Bay is an openaccess resource that has experienced a tragedy of the commons as shared resources by many parties. As a result, Mundu Bay has used excessively and ignored the balance of the ecosystem, especially if monitoring its impact not continuously. There is an assumption that the presence of Cirebon coal-fired power plant does not have negative implications on the environment thus insistence to fulfill energy needs also encourages the development of similar infrastructure in Cirebon namely PLTU Cirebon II (Muhaimin et al., 2015).

In 2015, the government built PLTU Cirebon II (capacity $1000 \mathrm{~mW}$ ) due to the large demand for electricity to drive development in Ciayumajakuning (Dewanto, 2016). The second coal-fired power plant will be full operation in 2022. Issue of decreasing the ecosystem quality continues to strengthen when fishermen found dead marine biota with body parts contaminated with pollutants from the coal-fired power plants. This problem eventually stopped without continued investigation and due process, due to conflicting agreements. Dualism of information is biased and affect decision-makers, hence the commitment to improve the water quality at Mundu Bay needs to be reviewed with other perspectives using remote sensing and geographic information systems as part of environmental management (Elhag et al., 2019; Ruslisan et al., 2016). Multi-spectral satellite imagery has multiple sensors that can be adjusted to the user 
needs and has a fairly short temporal resolution are useful as input datasets for GIS (Dede et al., 2019; Yan et al., 2015).

Remote sensing imagery can detect changes in temperature, dissolved oxygen, sediment loads, oil spills, waste concentrations, and other components accurately (Hafeez et al., 2018; Lubis et al., 2017; Widiawaty et al., 2020). The integration of remote sensing and GIS to see the impact before and after the construction-operation of the coal-fired power plant can be viewed from many parameters of water quality. The accuracy of remote sensing data will be higher if accompanied by in-situ field measurements or compared to other satellite imagery data (Murayama, 2012). In contrast to previous studies which examined one or two parameters of water quality due to the construction of power plants, this study seeks to assess total suspended solids (TSS), sea surface temperature (SST), phytoplankton (chlorophyll-A), and sea surface salinity (SSS or SS-Sal) levels in before-after the construction-operation of Cirebon coal-fired power plants (Miara et al., 2018; Rosen et al., 2015; Widyarani et al., 2019). Research on the development and operational impacts of the Cirebon coal-fired power plants is a need to respond to the information which circulating in the public given its considerable influence on the environment because it concerns sustainability and community livelihood. Based on these problems, this research seeks to uncover the impact of Cirebon coal-fired power plants on the water quality of Mundu Bay in Cirebon Regency, West Java, Indonesia.

\section{Research Method}

This research was conducted in the Mundu Bay around the PLTU Cirebon I and II sites. The area of interest (AOI) (Sanchez, 2014; Widiawaty \& Dede, 2018).

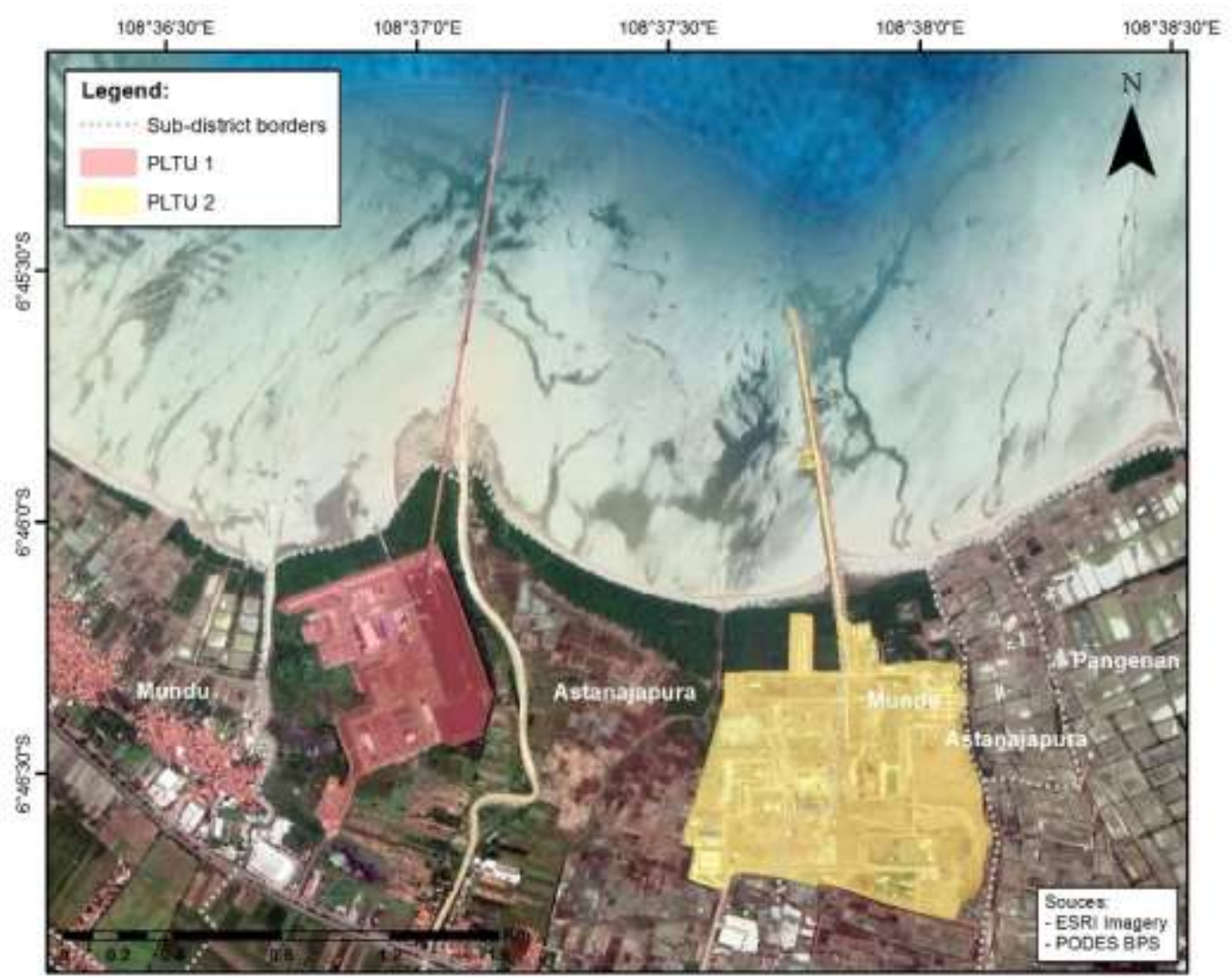

Figure 1. Research location shows the site of Cirebon steam power plan 


\subsection{Data Acquisition}

The main data in this study came from secondary sources. To increase validity and reduce information bias, secondary data used come from different sources - triangulation using other secondary data and primary sources (Fielding, 2012; Shelby \& Vaske, 2008). The selection of data sources is also adjusted to the purpose and efficiency of information acquisition, in this study most of the secondary data came from the United States Geological Survey (USGS), European Space Agency (ESA), and National Aeronautics and Space Administration (NASA) (Table 1).

Table 1. Satellite imageries for analysis

\begin{tabular}{|c|c|c|c|c|c|}
\hline Variables & Unit & Imageries & Years & Path/Row & Level \\
\hline \multirow{3}{*}{$\begin{array}{l}\text { Total suspended } \\
\text { solid (TSS) }\end{array}$} & \multirow[t]{3}{*}{$\mathrm{mg} / \mathrm{l}$} & Landsat-8 OLI (USGS) & 2014,2019 & 121065 & L1 \\
\hline & & Landsat-7 ETM+ (USGS) & 1999 & 121065 & L1 \\
\hline & & Sentinel-2 MSI (ESA) & 2019 & T49MBN & L1 \\
\hline \multirow{3}{*}{$\begin{array}{l}\text { Sea surface } \\
\text { temperature } \\
\text { (SST) }\end{array}$} & \multirow[t]{3}{*}{${ }^{\circ} \mathrm{C}$} & Landsat-8 OLI (USGS) & 2014,2019 & 121065 & L1 \\
\hline & & Landsat-7 ETM+ (USGS) & 1999 & 121065 & L1 \\
\hline & & MODIS Aqua "MYD11" (NASA) & 2019 & H28V09006 & L1 \\
\hline \multirow{3}{*}{$\begin{array}{l}\text { Phytoplankton } \\
\text { concentration } \\
\text { (Chlorophyll-A) }\end{array}$} & \multirow[t]{3}{*}{$\mathrm{mg} / \mathrm{m}^{3}$} & Landsat-8 OLI (USGS) & 2014,2019 & 121065 & L1 \\
\hline & & Landsat-7 ETM+ (USGS) & 1999 & 121065 & L1 \\
\hline & & Sentinel-2 MSI (ESA) & 2019 & T49MBN & L1 \\
\hline \multirow{3}{*}{$\begin{array}{l}\text { Sea surface } \\
\text { salinity (SSS) }\end{array}$} & \multirow[t]{3}{*}{ Psu } & Landsat-8 OLI (USGS) & 2014,2019 & 121065 & L1 \\
\hline & & Landsat-7 ETM+ (USGS) & 1999 & 121065 & L1 \\
\hline & & Sentinel-2 MSI (ESA) & 2019 & T49MBN & L1 \\
\hline
\end{tabular}

This research not only uses secondary sources, but also uses primary sources through field observation and in-situ measurements in 2019. The number of sampling points for each variable varies according to the needs and abilities of researchers (see Appendix). In this study, only chlorophyll-A samples were not tested in-situ due to time and cost constraints, so the tests were only based on comparison of remote sensing data from two different sensors. When referring to datasets used, the main data was based on the availability on before and after the Cirebon coalfired power plants which ranges from 1999-2019. Therefore, data from Landsat series images are the main data in this study. The difference in variables and characteristics for each object on the surface of the earth causes different processing algorithms to produce the necessary information. Before entering these algorithms, satellite image data requires preprocessing steps through geometry, atmospheric, and radiometric corrections (Widiawaty, 2019; Young et al., 2017). In this study, the digital number (DN) on each band of satellite images is converted into reflectance value using the DOS1 method. The satellite image processing algorithm to obtain information related to the research variables is presented in Table 2 - These algorithms are suitable for dynamics analysis of the tropical environment in Indonesia which has high rainfall and temperature (megathermal) with the monsoons influence.

\subsection{Data Analysis}

This research is classified as a quantitative approach because variables of water quality are presented in numerical descriptions and statistical analysis (Eyisi, 2016). Disclosure of changes in water quality is done by analyzing secondary data which are combined with a primary data from field measurements and other data sources as validators in order to answer research pro- 
Table 2. Algorithms for processing satellite data

\begin{tabular}{|c|c|c|}
\hline Variables & Dataset & Algorithms \\
\hline \multirow[t]{3}{*}{ TSS } & Landsat & Parwati and Purwanto (2017) \\
\hline & series and & $\operatorname{TSS}_{(\mathrm{mg} / \mathrm{l})}=0.6211 \times\left(7.9038 \times \operatorname{Exp}(23.942 \times \mathrm{RB} \rho)^{0.9645}\right.$ \\
\hline & Sentinel-2 & Where $\mathrm{RB} \rho$ is the BoA reflectance value of the red band. \\
\hline \multirow[t]{4}{*}{ SST } & Landsat & Nurdian et al. (2020), \\
\hline & series and & $\mathrm{L}_{\lambda}=M_{L} \times Q_{c a l}+A_{L}$ \\
\hline & & $\mathrm{T}=\frac{\mathrm{K}_{2}}{\ln \left(\frac{\mathrm{K}_{1}}{\mathrm{~L}_{\lambda}}+1\right)}$ \\
\hline & & $\begin{array}{l}\text { Where } L_{\lambda} \text { is the spectral radiation value of ToA, ML as the thermal band } \\
\text { rescaling factor, } Q_{c a l} \text { is the total heat energy, AL shows the value of the } \\
\text { thermal band constant, T is the temperature value in Kelvin units, and } \\
K_{2} / K_{1} \text { as the calibration constant obtained from the metadata. }\end{array}$ \\
\hline \multirow[t]{3}{*}{ Chlorophyll-A } & Landsat & Nuriya et al. (2010) \\
\hline & $\begin{array}{l}\text { series and } \\
\text { Sentinel-2 }\end{array}$ & Chlorophyll $-\mathrm{A}_{\left(\mathrm{mg} / \mathrm{m}^{3}\right)}=0.2818\left(\frac{\mathrm{NIR} \rho+\mathrm{SWIR} \rho}{\mathrm{RB} \rho}\right)$ \\
\hline & & $\begin{array}{l}\text { Where NIRp is the BoA value of near infrared band, shortwave infrared } \\
\text { band, and red band. }\end{array}$ \\
\hline \multirow[t]{3}{*}{ SS-Sal } & Landsat & Ladya et al. (2015) \\
\hline & $\begin{array}{l}\text { series and } \\
\text { Sentinel-2 }\end{array}$ & $\begin{array}{l}\mathrm{L}_{(\mathrm{psu})}=-42.72 \times\left(\left(-61.182 \times \mathrm{B}^{3}+79.129 \times \mathrm{B}^{2}-34.022 \times \mathrm{B}+4.865\right)+\right. \\
32.702)\end{array}$ \\
\hline & & $\begin{array}{l}\text { Where } B \text { is the blue chromatization of the divided blue band blue band } \\
+ \text { green band + red band. All bands in the equation use BoA reflectance } \\
\text { values. }\end{array}$ \\
\hline
\end{tabular}

blems (Johnston, 2014). In this study, the data sample used saturated sampling which covered all Mundu Bay waters in accordance with AOI. Data from the water quality algorithms are then tested for validity by comparing the results from two different satellites in the same year. Validity test using the Spearman Rank correlation (Equation 1) because all the results of the processing have non-normal distribution (Setiawan et al., 2019). Data prove to be valid as indicated by the minimum significance value of 0.05 , thus analysis can be continued using the Mann-Whitney U-Test as presented in Equations 2 (Dadson, 2017; Milenovic, 2011; SanyéMengual et al., 2018). Details about the data analysis stage is presented in Figure 2.

$$
\rho=\frac{6 \sum d_{i}^{2}}{n\left(n^{2}-1\right)}
$$

Where $\rho$ indicates the level of correlation ( $r$-value), $n$ the amount of data observed, and $d$ is the difference value of paired data. Correlation is significant if the $\rho>\rho$-table at a confidence level of 95 to 99 percent.

$$
U_{i}=n_{i} \times n_{i+1}+\left[\frac{n_{i}\left(n_{i}+1\right)}{2}\right]-\sum R_{i}
$$

Where $U$ is the value of the Mann-Whitney test results, $n$ indicates the number of samples for each dataset, and $R$ as the number of ranks for each dataset. Significant difference (take the lowest value from $U_{i}$ or $U_{i+1}$ ) if $U<U$-table. 


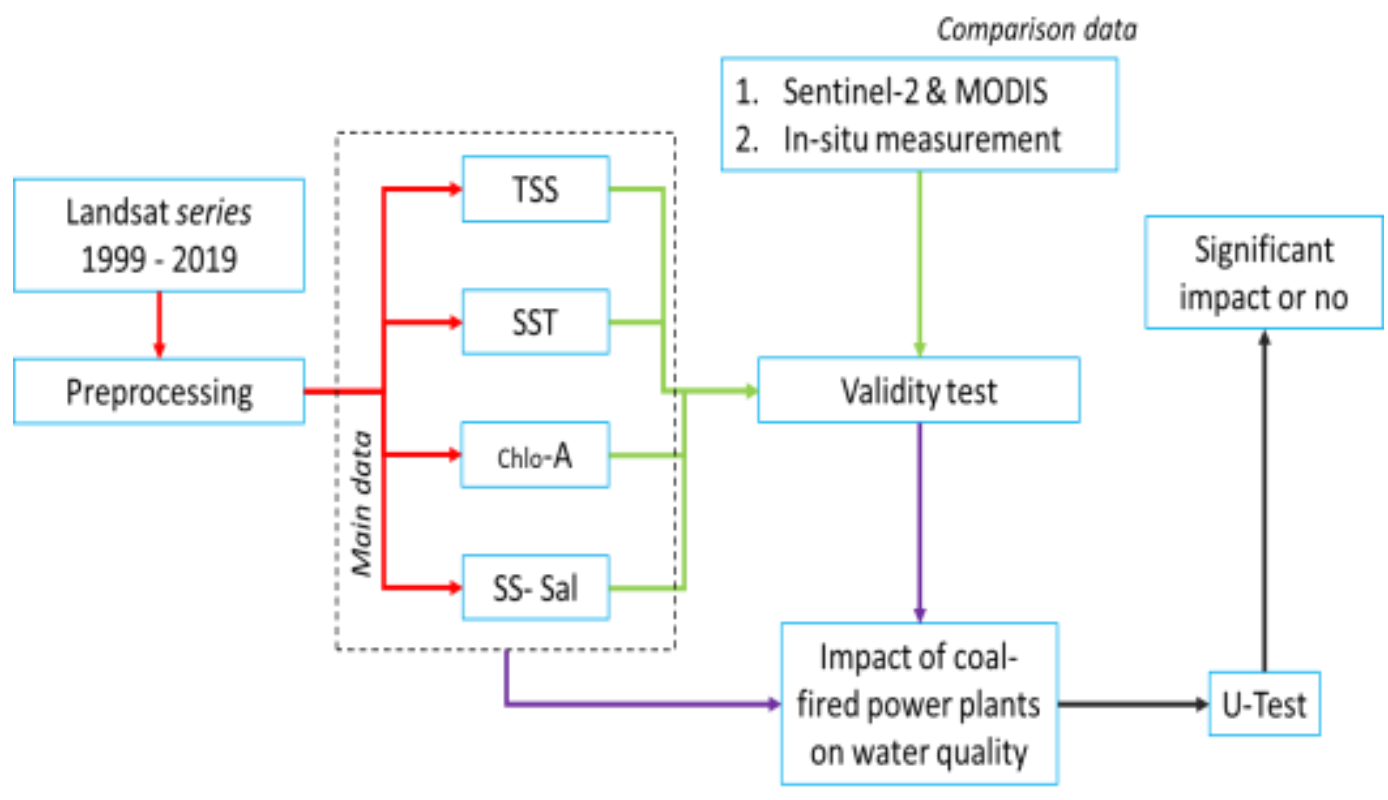

Figure 2. Research scheme and data analysis

\section{Results and discussion}

The presence of coal-fired power plants is expected to increase electricity capacity. PLTU Cirebon I which began operating in 2011 has a similar goal to support many economic sectors in Java. Since the establishment of the coal-fired power plant, the local community has felt various changes to the environment and socio-economic conditions because the fishermen's yield is decreased significantly compared to before the construction and operation of power plant. This is due to the environmental impact caused by the coal-fired power plant on the water quality and marine biota (Myllyvirta \& Chuwah, 2017).

\subsection{Water quality in Mundu bay}

When compared with data in 1999-2014, the presence of PLTU Cirebon I was able to increase the TSS level by an average of $18.75 \mathrm{mg} / \mathrm{l}$ (156.25 percent) (Figure 3) . This condition was followed by a decrease in SST of $4.68{ }^{\circ} \mathrm{C}$ to below $18^{\circ} \mathrm{C}$, thus disrupting the growth and breeding of phytoplankton as primary productivity for waters (Figure 4). Even the average levels of phytoplankton (chlorophyll-A) decreased by more than 50 percent from 1999-2014 (Figure 5). PLTU Cirebon I also caused a decrease in salinity (SS-Sal) of 17.6 psu thus complaints from the fishing communities around the coal-fired power plants occur due to changes in the quality of the water that is declining (Figure 6), ecosystem balance is disrupted and has an impact on the decline in yield catches due to pollutant compounds increasing as a limiting factor, in addition to restrictions on access to certain water spaces in Mundu Bay (Nurhasanah, 2017; Tarunamulia et al., 2019).

Despite changes in water quality that affect the socio-economic conditions of the surrounding community, the electricity supply program is continuing. The PLTU Cirebon II development also contributed to changes in the water quality of Mundu Bay, especially in increasing TSS levels and decreasing salinity. The presence of PLTU Cirebon II did not change as much as PLTU Cirebon I, even though the TSS levels rose more than three times compared to before the presence of two coal-fired power plants (see Table 3). Besides the numerical 
description system, changes in the water quality in Mundu Bay can also be viewed from a spatial perspective. Before PLTU Cirebon I existed, precisely in 1999, sea waters close to the mainland had low TSS levels, were clear and sunlight was able to penetrate to the bottom of the waters except in areas close to river estuaries (Gholizadeh et al., 2016; Widiawaty et al., 2020). Socioeconomically, this condition has enabled fishermen to catch various species of marine animals such as fish, shrimp, crab, and shellfish. The unpolluted sea which is relatively close to traditional harbors also reduced operational cost. The presence of Cirebon coal-fired power plants along with anthropogenic landforms that stretch to the waters of Mundu Bay also changed the spatial distribution of TSS. Ironically, it is difficult to find proper seawater quality with low TSS near the coast now after the coal-fired power plants exist. Even in 2019 - after the construction and operation of the PLTU Cirebon II - waters with low TSS levels cannot be found up to a distance of five kilometers from the coast (Figure 3).

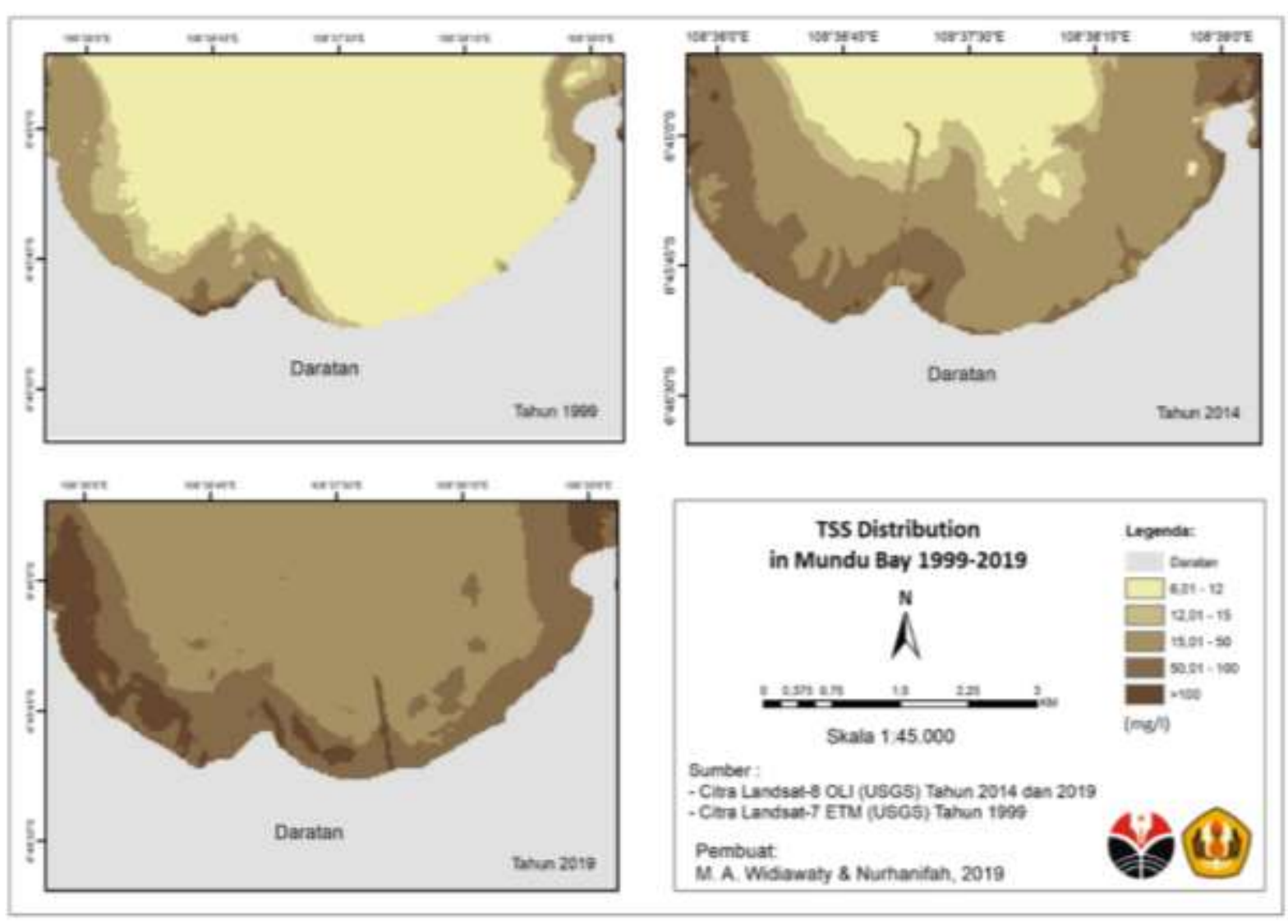

Figure 3. TSS distribution in Mundu bay 1999-2019

In contrast to other water quality variables, SST has increase and decrease after the coalfired power plants operation (Figure 4). During the construction and operation of the PLTU Cirebon I, SST distribution changed to be lower. However, this condition has changed again after the construction and operation of the PLTU Cirebon II, where SST has increased again with a distribution pattern and values similar to those in 1999 (Figure 4). The returns of SST in its previous form did not mean as recover for the water quality in Mundu Bay because habitat suitability for marine-aquatic ecosystems is not only determined by temperature changes (Choi 
et al., 2012). The increase in SST is hypothetically caused by thermal water discharge from the power plant as well as increased water turbidity due to TSS caused by PLTU Cirebon I operation in 2014.

Table 3. Water quality dynamic in Mundu bay from satellite imageries

\begin{tabular}{lrrrrr}
\hline \multicolumn{1}{c}{ Variables } & \multicolumn{1}{c}{ Year } & \multicolumn{1}{c}{ Min } & \multicolumn{1}{c}{ Max } & \multicolumn{1}{c}{ Mean } & \multicolumn{1}{c}{ Std. Dev. } \\
\hline TSS $(\mathrm{mg} / \mathrm{l})$ & 1999 & 6.75 & 4.95 & 12.00 & 11.13 \\
& 2014 & 7.42 & 1143.6 & 30.75 & 27.57 \\
& 2019 & 21.25 & 270.59 & 49.49 & 30.18 \\
SST $\left({ }^{\circ} \mathrm{C}\right)$ & 1999 & 20.96 & 26.28 & 22.34 & 0.44 \\
& 2014 & 16.34 & 20.35 & 17.66 & 0.59 \\
& 2019 & 21.94 & 25.83 & 23.60 & 0.52 \\
Chlorophy-A & 1999 & 0.14 & 1.83 & 0.37 & 0.15 \\
$\left(\mathrm{mg} / \mathrm{m}^{3}\right)$ & 2014 & 0.09 & 1.43 & 0.18 & 0.08 \\
& 2019 & 0.14 & 1.52 & 0.20 & 0.08 \\
SS-Sal & 1999 & 5831.43 & 5882.63 & 5871.65 & 11.45 \\
(psu) & 2014 & 5821.73 & 5880.13 & 5854.05 & 11.57 \\
& 2019 & 5798.38 & 5856.36 & 5836.53 & 7.88 \\
\hline
\end{tabular}

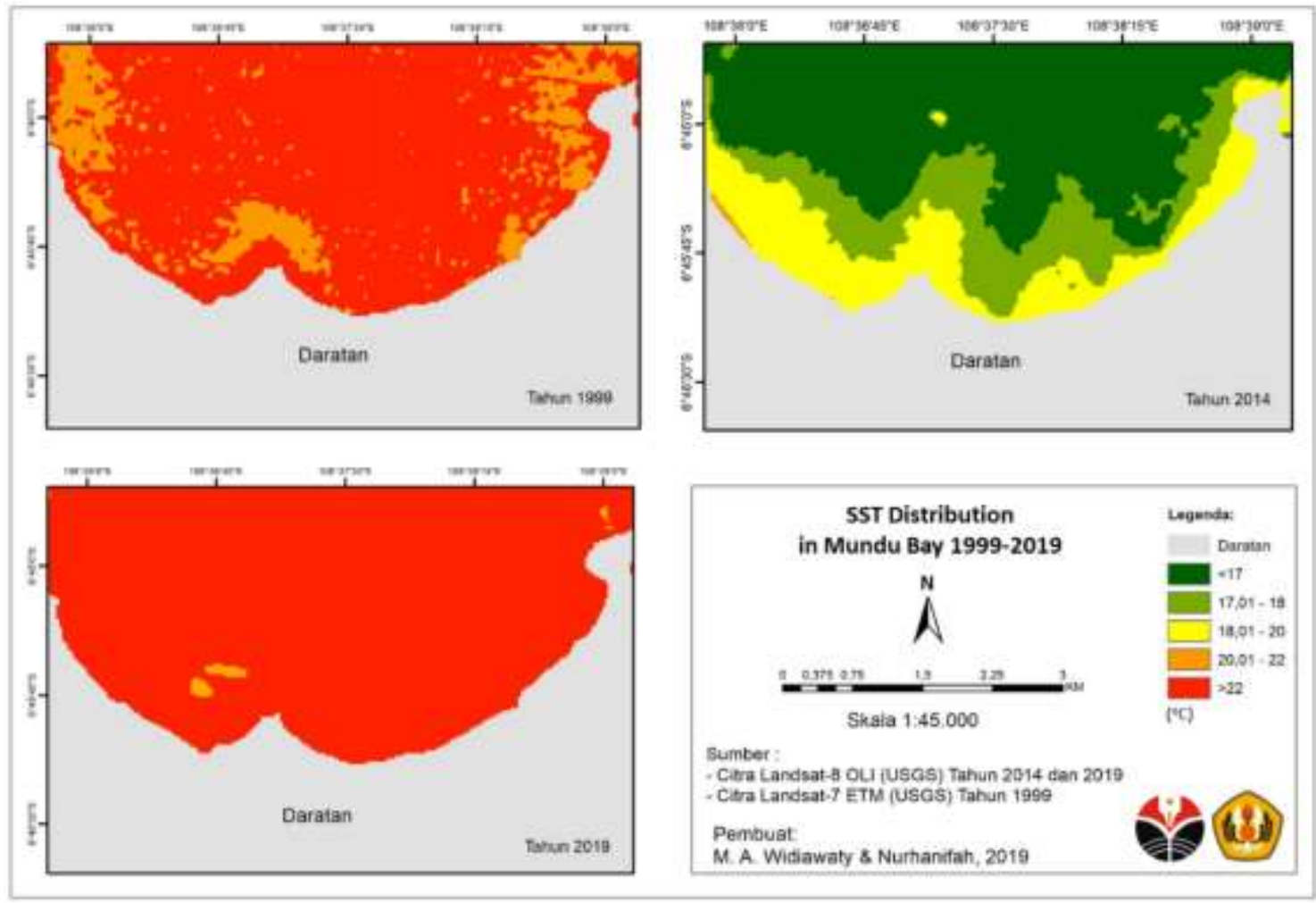

Figure 4. SST distribution in Mundu bay 1999-2019 


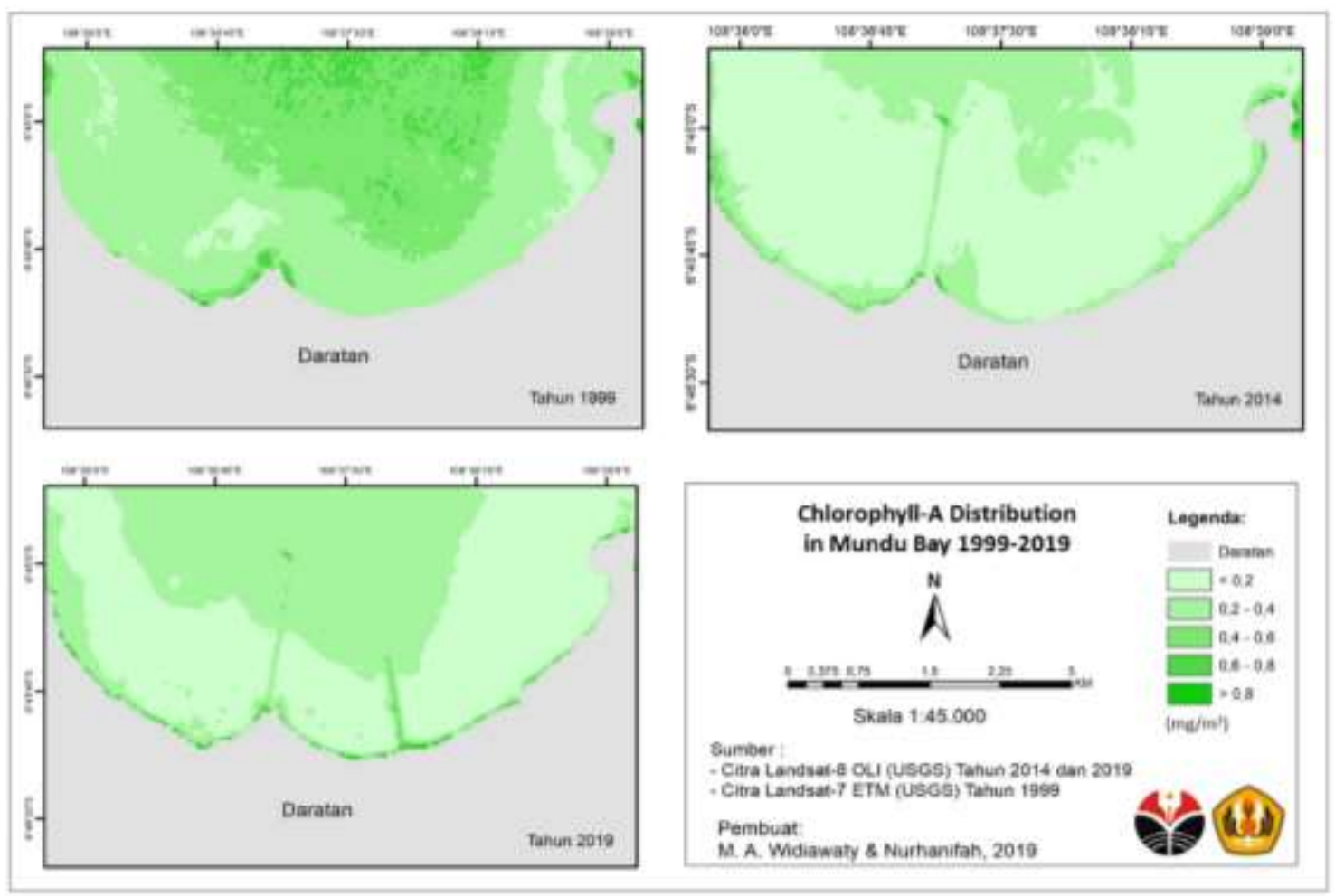

Figure 5. Chlorophyll-A distribution in Mundu bay 1999-2019

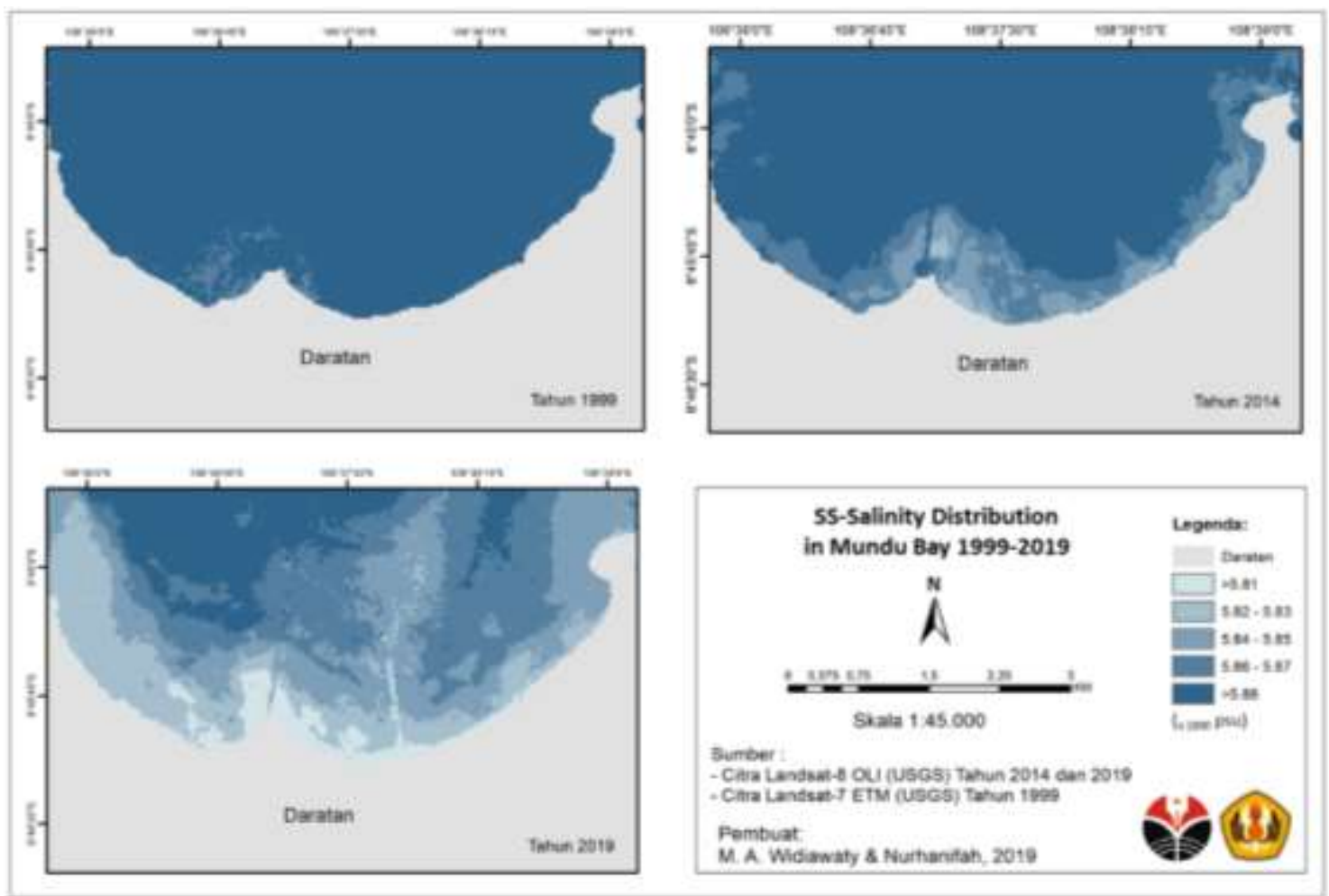

Figure 6. SS-Sal distribution in Mundu bay 1999-2019 
TSS was increasing in Mundu Bay and coming closer to the mainland, it decreasing chlorophyll-A at the same time. In 1999, chlorophyll-A was abundant from the coast - less than one kilometer. This condition persisted until the presence of chlorophyll-A decreased due to the increasing TSS after the operation of PLTU Cirebon in 2014, thus Mundu Bay has low primary productivity (Figure 3 and Figure 5). The spatial distribution of chlorophyll-A has a similar pattern with surface salinity levels, its distribution continues to decrease in near the coastal area (Figure 6). Despite SST rising, salinity value actually continues to decrease due to reduction in salt compounds and substituted by TSS and freshwater from rivers and rainfall (Fang et al., 2010). In addition, the salinity changes can also be caused by thermal water waste, it is able to decipher the salt compounds bonding. Reduced salinity means reducing the ideal habitat for marine biota and decreasing the yield of salt-embankment.
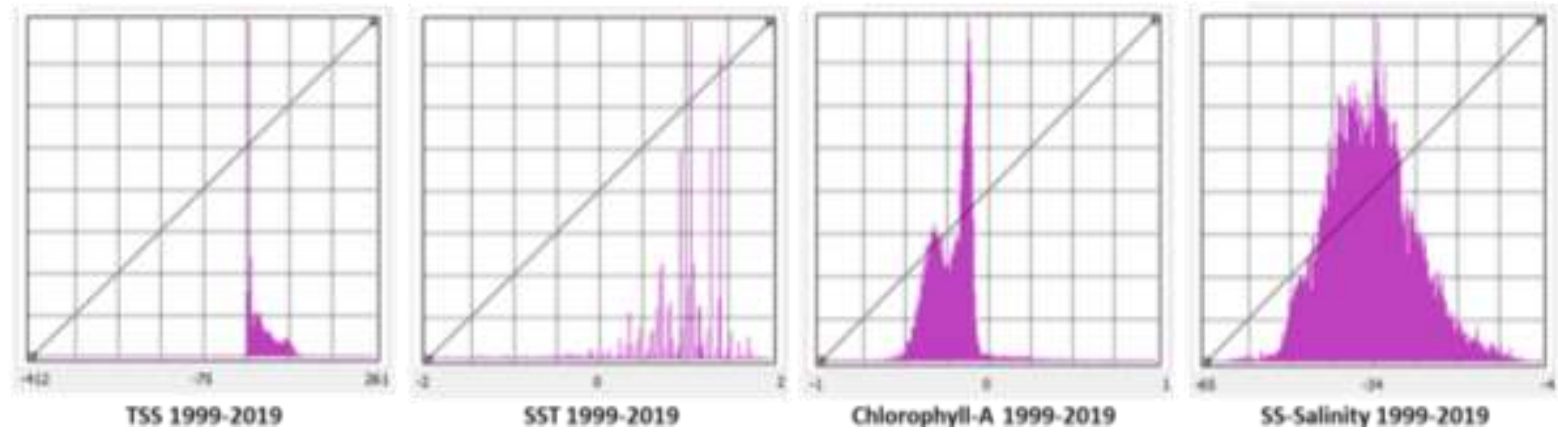

Figure 7. Histogram of water quality changes in Mundu bay

The spatial distribution of the Mundu Bay from 1999-2019 resulted in ecosystem changes that were not favorable for the community, the changes of these variables have influenced for the aquatic ecosystem (Figure 7). In the long term, the lack of supervision and inaccurate environmental management of coal-fired power plants will lead to a bad policy that triggers poor execution for the community and Mundu Bay as open ecosystems. Whereas fisheries and marine activities are the basic sectors that have a multiplier effect on the socio-economic in Cirebon, it has a strong influence on other i.e industry and service sectors (Dede et al., 2016).

\subsection{Impact of coal-fired power plant on water quality}

To know the impact of Cirebon coal-fired power plants on water quality begins using statistical tests. Data validity testing shows that the information from the Landsat series with other satellite data was declared feasible. This result shows the highest correlation in TSS, even though the correlation value for these variables is significant with $\mathrm{p}$-value $\leq 0.05$ (see Table 4) and its suitable for further analysis (Nudian et al., 2019). Meanwhile, when we referring to data from in-situ measurements for TSS, SST, and salinity also show information from multi-spectral satellite imagery was valid. Table 5 shows that the TSS has the highest correlation. Thus both the validity test with other imageries and in-situ samples of these variables are declared eligible for environmental impact analysis by coal-fired power plants.

Changes in the aquatic environment quality due to Cirebon coal-fired power plants are known from the Mann-Whitney U-Test using Landsat series imagery data for the periods on before and after of infrastructure development. The test shows environmental quality changes as indicated by high $\mathrm{U}$-value for all variables, it indicates significant difference in the Mundu Bay ecosystem from 1999 to 2019. The highest U-value come from chlorophyll-a which means an 
extreme changes in food chain of aquatic environment - the phytoplankton population continues to decrease and detrimental to the fishing community. Based on the results, we known that the development and operation of Cirebon coal-fired power plants have significant impact on the water quality (Table 6).

Table 4. Validation of water quality from inter-satellite imageries

\begin{tabular}{lrll}
\hline \multicolumn{1}{c}{ Variables } & r-value & Sig. & \multicolumn{1}{c}{ Validity } \\
\hline TSS & 0.893 & 0.000 & Valid \\
SST & 0.386 & 0.000 & Valid \\
Chlorophyll-A & 0.499 & 0.000 & Valid \\
SS-Sal & 0.767 & 0.000 & Valid \\
\hline
\end{tabular}

Table 5. In-situ measurement validation for satellite imagery algorithms

\begin{tabular}{lrrrl}
\hline \multicolumn{1}{c}{ Variables } & $\mathrm{n}$ (point) & \multicolumn{1}{c}{ r-value } & \multicolumn{1}{c}{ Sig. } & Validity \\
\hline TSS & 8 & 0.778 & 0.023 & Valid \\
SST & 26 & 0.437 & 0.026 & Valid \\
SS-Sal & 26 & 0.437 & 0.026 & Valid \\
\hline
\end{tabular}

Table 6. U-Test result of water quality in before and after the two steam power plan exist

\begin{tabular}{lrrl}
\hline \multicolumn{1}{c}{ Variables } & Mann-Whitney U-value & \multicolumn{1}{c}{ Sig. } & Information \\
\hline TSS & 3645336.00 & 0.000 & Different and significance \\
SST & 12498092.00 & 0.000 & Different and significance \\
Chlorophyll-A & 20315663.50 & 0.000 & Different and significance \\
SS-Sal & 2813980.50 & 0.000 & Different and significance \\
\hline
\end{tabular}

Besides has negative impacts on coastal ecosystems and its surrounding social systems, changes in water quality variables also interact with each other (Table 7). Increasing TSS triggers SST , chlorophyll-A, and salinity significantly decrease. In Mundu Bay, TSS plays a vital role in this ecosystem. TSS increasing is caused by the wharf (jetty) of coal-fired power plants, jetty able to changing the flow of sea current and able to accumulated sediments (Widiawaty et al., 2020). TSS increasing can be caused by the combustion dust and coal debris which carried in run-off water (Shahzad Baig \& Yousaf, 2017).

Table 7. Correlation between variables of water quality

\begin{tabular}{lrrrr}
\hline \multicolumn{1}{c}{ Variables } & \multicolumn{1}{c}{ TSS } & \multicolumn{1}{c}{ SST } & \multicolumn{1}{c}{ Chlorophyll-A } & \multicolumn{1}{c}{ SS-Sal } \\
\hline TSS & 1 & -0.305 & -0.323 & -0.451 \\
SST & -0.305 & 1 & 0.352 & 0.494 \\
Chlorophyll-A & -0.323 & 0.352 & 1 & 0.214 \\
SS-Sal & -0.451 & 0.494 & 0.214 & 1 \\
\hline
\end{tabular}




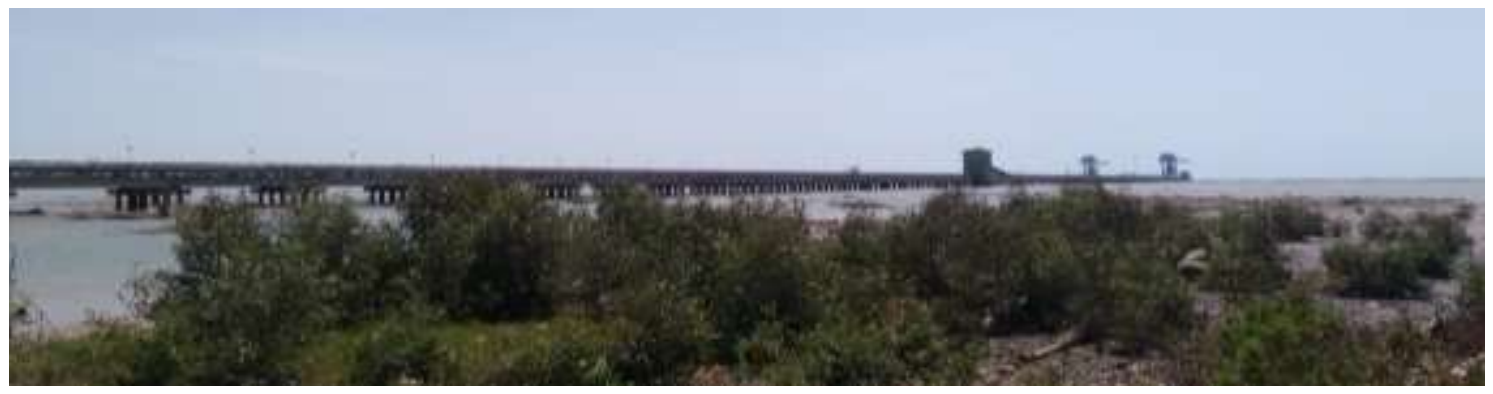

Figure 8. Jetty of the Cirebon steam power plant I

The Cirebon coal-fired power plants have a direct impact on the sustainability of the ecosystem and hampered the economic activities of the surrounding which is predominantly dependent on the sea. Before the PLTU Cirebon II was built, people's complaints related to income from fishing were not heard because it was still sufficient to life needs. Currently, the presence of Cirebon coal-fired power plants have caused coastal landscape change and increasing waste accumulation in Mundu Bay. This condition is not optimal for marine biota growth and brings detrimental to fishermen yields. In addition, the waste material also has the potential to contain heavy metals which can cause health problems in the future (Miara et al., 2018). Even though the construction and operations have many negative impact on the environment, Indonesia's government has planning to build a coal-fired power plant near Mundu Bay as known as PLTU Cirebon III.

\section{Conclusion}

The Cirebon coal-fired power plants construction has met environmental requirements in administrative document, but its negative impacts on the ecosystem and surrounding social systems are still occurring. This study shows that the presence of coal-fired power plants has significantly reduced water quality in Mundu Bay, its presence is able to change TSS, SST, Chlorophyll-A, and salinity which interfere the marine biota growth and causing fishermen to suffer losses. Water quality changes create a multiplier effect for economic activities depend on marine biological resources. Stakeholders should be able to review environmental management of Cirebon coal-fired power plants to meet sustainability criteria. Based on this study, satellite imageries are effectives to assess the changes of aquatic environment. In the future, the use of remote sensing technology, both airborne and satellite, can continue to be optimized for environmental monitoring and auditing.

\section{Acknowledgement}

Thank you for the local people who help us to get water samples and willing as informants. Special thanks for Geosac's board of jury which chosen our manuscript as the best paper.

\section{References}

Abdullah, O. S. (2017). Ekologi manusia dan pembangunan berkelanjutan. Jakarta: Gramedia Pustaka Utama.

Aissa, N., \& Hartono, D. (2016). The impact of geothermal energy sector development on electricity sector in Indonesia economy. Buletin Ekonomi Moneter Dan Perbankan, 19(2), 153-176.

Cahyadi. (2011). Kajian Teknisk Pembangkit LIstrik Berbahan Bakar Fossil. Jurnal Ilmiah Teknologi Energi, 1(12), 21-32.

Choi, K., Kim, Y., Lee, J., Wang, S., Lee, M., Lee, P., ... Soh, H. (2012). Thermal impacts of a coal power plant 
on the plankton in an open coastal water environment. Journal of Marine Science and Engineering, 20(2), 187-194.

Dadson, S. J. (2017). Statistical Analysis of Geographical Data: An Introduction. Oxford: John Wiley \& Sons ltd.

Dede, M., Pramulatsih, G. P., Widiawaty, M. A., Ramadhan, Y. R., \& Ati, A. (2019). Dinamika suhu permukaan dan kerapatan vegetasi di Kota Cirebon. Jurnal Meteorologi Klimatologi Dan Geofisika, 6(1), 23-30.

Dede, M., Sewu, R. S. B., Yutika, M., \& Ramadhan, F. (2016). Analisis potensi perekonomian sektor pertanian, kehutanan, dan perikanan serta pertambangan dan penggalian di Pantura Jawa Barat. In Prosiding Seminar Nasional Epicentrum 5.5: Optimalisasi Sumber Daya Alam Matra Darat dan Matra Lautan untuk Ketahanan Pangan dan Kesehatan dalam Konteks Nasionalisme. Bandung: Departemen Pendidikan Geografi, Fakultas Pendidikan Ilmu Pengetahuan Sosial Universitas Pendidikan Indonesia.

Dede, M., Widiawaty, M. A., Nurhanifah, ISmail, A., Artati, A. R. P., Ati, A., \& Ramadhan, Y. R. (2020). Estimasi peruahan kualitas udara berbasis citra satelit penginderaan jauh di sekitar PLTU Cirebon. Jambura Geoscience Review, 2(2), 78-87. http://doi.org/10.34312/jgeosrev.v2i2.5951

Dewanto, H. (2016). Analisis Dampak Lingkungan Hidup (ANDAL) Rencana Pembangunan dan Operasi Pembangkit Listrik Tenaga Uap (PLTU) Cirebon Kapasitas 1 X 1.000 Mw Kabupaten Cirebon Jawa Barat. Jakarta.

Elhag, M., Gitas, I., Othman, A., Bahrawi, J., \& Gikas, P. (2019). Assessment of Water Quality Parameters Using Temporal Remote Sensing Spectral Reflectance in Arid Environmentas, Saudi Arabia. Water, 11, 556. http://doi.org/10.3390/w11030556

Eyisi, D. (2016). he Usefulness of Qualitative and Quantitative Approaches and Methods in Researching Problem-Solving Ability in Science Education Curriculum. Journal of Education and Practice, 7(15), 91-100.

Fang, L., Chen, S., Wang, H., Qian, J., \& Zhang, L. (2010). Detecting marine intrusion into rivers using EO-1 ALI satellite imagery: Modaomen Waterway, Pearl River Estuary, China. International Journal of Remote Sensing, 31(15), 4125-4146. http://doi.org/10.1080/01431160903229218

Fielding, N. G. (2012). Triangulation and Mixed Methods Designs: Data Integration With New Research Technologies. Journal of Mixed Methods Research, 6(2), 124-136. http://doi.org/10.1177/1558689812437101

Gholizadeh, M. H., Melesse, A. M., \& Reddi, L. (2016). A Comprehensive Review on Water Quality Parameters Estimation Using Remote Sensing Techniques. Sensors, 16, 1298. http://doi.org/10.3390/s16081298

Ha-duong, M., Truong, H., Nguyen, H. N., \& Trinh, H. A. N. (2016). Synthesis Report on Socio-environmental Impacts of Coal and Coal-fired Power Plants in Vietnam. Retrieved from https://hal-enpc.archivesouvertes.fr/hal-01441680

Hafeez, S., Wong, M. S., Abbas, S., Kwok, C. Y. T., Nichol, J., Lee, K. H., ... Pun, L. (2018). Detection and Monitoring of Marine Pollution Using Remote Sensing Technologies. In Monitoring of Marine Pollution. IntechOpen.

Hudaya, G., \& Madiutomo, N. (2019). The ability of Indonesian coal to meet the 2050 demand. Indonesian Mining Journal, 22(2), 107-128. http://doi.org/10.30556/imj.Vol22.No2.2019.689

Johnston, M. P. (2014). Secondary Data Analysis : A Method of which the Time Has Come. Qualitatie and Quantitatie Methods in Libraries, 3, 619-626.

Kumar, S., Katoria, D., \& Sehgal, D. (2013). Environment Impact Assessment of Thermal Power Plant for Sustainable Development. InternationalJOurnal of Environmental Engineering and Management, 4(6), 567-572.

Ladya, C. D., Supriatna, \& Rokhmatullah. (2015). Zonasi Estuari Cimandiri Berdasarkan Salinitas Permukaan Perairan. Laporan Penelitian. Uiniversitas Indonesia.

Legino, S., Arianto, R., \& Pasra, N. (2019). The attainment of 100 percent electrification ratio in the archipelago of Indonesia by people way electricity initiative. Journal of Physics: Conf. Series, 1282, 12057. http://doi.org/10.1088/1742-6596/1282/1/012057 
Levine, S., \& Kendall, K. (2006). Energy Efficiency and Conservation: Opportunities, Obstacles, and Experiences. Vermont Journal of Environmental Law, 8(1), 101-113.

Lubis, M. Z., Gustin, O., Anurogo, W., Kausarian, H., Anggraini, K., \& Hanafi, A. (2017). Penerapan teknologi penginderaan jauh di bidang pesisir dan lautan. Oseana, XLII(3), 56-64.

Miara, A., Charles, J. ., Macnick, J. E., Tidwell, V. C., Fekete, B., Corsi, F., \& Newmark, R. (2018). Thermal pollution impacts on rivers and power supply in the Mississippi River watershed. Environmental Research Letters, 13, 34033.

Milenovic, Z. M. (2011). Application of Mann-Whitney U test in research pf professional training of primary school teachers. Metodički Obzori, 6(1), 73-79.

Muhaimin, Sugiharto, E., \& Suratman, A. (2015). Air pollution simulation from Cirebon Power Plant activity. Eksakta: Jurnal Ilmu-Ilmu MIPA, 1(5), 14-22.

Murayama, Y. (2012). Progress in Geospatial Analysis. Japan: Springer.

Myllyvirta, L., \& Chuwah, C. (2017). Assessing the air quality, toxic and health impacts of coal-fired power plants surrounding the Jakarta megacity. Jakarta.

NRDC. (2014). Protecting Our Waters from Toxic Power Plant Discharges and Reducing Water Use in the Process.

Nudian, W., Dede, M., Widiawaty, M., Ramadhan, Y. R., \& Purnama, Y. (2019). Pemanfaatan sensor mikro DHT11-Arduino untuk monitoring suhu dan kelembaban udara. In Seminar Nasional Pertemuan Ilmiah II - Ilmu Lingkungan Tahun 2019. Bandung: Magister Ilmu Lingkungan Universitas Padjajaran.

Nurdian, W., Dede, M., Widiawaty, M. A., Ramadhan, Y. R., \& Purnama, Y. (2020). Pemanfaatan Sensor Mikro DHT11-Arduino untuk Monitoring Suhu dan Kelembaban Udara. In Prosiding PIT dan Semnas Ilmu Lingkungan "Harmony with Nature" (pp. 1-13).

Nurhasanah, T. N. (2017). Pencemaran Udara Akibat Penggunaan Batubara sebagai Sumber Energi Pembangkit Listrik Tenaga Uap (PLTU) Kecamatan Astanajapura Kabupaten Cirebon di Hubungkan dengan Undang-Undang Nomor 32 Tahun 2009 Tentang Perlindungan dan Pengelolaan Lingkungan Hidup. Universitas Pasundan.

Nuriya, H., Hidayah, Z., \& Nugraha, W. A. (2010). Pengukuran konsentrasi klorofil-a dengan pengolahan citra landsat ETM-7 dan uji laboratorium di perairan Selat Madura Bagian Barat. Jurnal Kelautan: Indonesian Journal of Marine Science and Technology, 3(1), 60-65.

Parwati, E., \& Purwanto, A. D. (2017). Time series analysis of total suspended solid (TSS) using Landsat data in Berau coastal area, Indonesia. International Journal of Remote Sensing and Earth Sciences, 14(1), 61-70.

Prima, A. R. (2018). PLTU Cirebon Power Pelopor Teknologi Batubara Bersih. Engineer Weekly, 8, 1-8.

Rosen, M. A., Bulucea, C. A., Mastorakis, N. E., Bulucea, C. A., Jeles, A. C., \& Brindusa, C. C. (2015). Evaluating the Thermal Pollution Caused by Wastewaters Discharged from a Chain of Coal-Fired Power Plants along a River. Sustainability, 7, 5920-5943. http://doi.org/10.3390/su7055920

Rosyid, F. A., \& Adachi, T. (2016). Forecasting on Indonesian Coal Production and Future Extraction Cost: A Tool for Formulating Policy on Coal Marketing. Natural Resources, 7, 677-696. http://doi.org/10.4236/nr.2016.712054

Ruslisan, Kalam, N. H., Dwininta, A. C., Habibi, M. H., Rahayu, E. T., Dewi, N., ... Widyatmanti, W. (2016). Water Quality Assessment Using Remote Sensing and GIS for In-shore Marine Environment Suitability. Aquacultura Indonesiana, 17(2), 46-53.

Sanchez, J. O. (2014). Coal as a Marine Pollutant. World Maritime University.

Sanyé-Mengual, E., Specht, K., Krikser, T., Vanni, C., Pennisi, G., Orsini, F., \& Gianquinto, G. P. (2018). Social acceptance and perceived ecosystem services of urban agriculture in Southern Europe: The case of Bologna, Italy. PLoS ONE, 13(9), e0200993. http://doi.org/10.1371/journal.pone.0200993

Setiawan, I., Dede, M., Sugandi, D., \& Widiawaty, M. A. (2019). Investigating Urban Crime Pattern and Accessibility Using Geographic Information System in Bandung City. KnE Social Sciences, 535-548. http://doi.org/10.18502/kss.v3i21.4993

Shahzad Baig, K., \& Yousaf, M. (2017). Coal Fired Power Plants: Emission Problems and Controlling 
Techniques. Journal of Earth Science \& Climate Change, 8, 404. http://doi.org/10.4172/21577617.1000404

Shelby, L. B., \& Vaske, J. J. (2008). Understanding Meta-Analysis: A Review of the Methodological Literature. Leisure Science, 30, 96-110. http://doi.org/10.1080/01490400701881366

Tarunamulia, Hasnawi, Asaf, R., \& Faizal, A. (2019). Environmental characteristics and management challenges of brackishwater fish ponds in Cirebon Regency, West Java Province, Indonesia: a finescale GIS Approach. IOP Conference Series: Earth and Environmental Science, 370, 12067. http://doi.org/doi:10.1088/1755-1315/370/1/012067

Untsa, Q. D. (2017). Mekanisme Penunjukan Langsung Pada Pembangunan Infrastruktur Ketenagalistrikan Dalam Perspektif Hukum Persaingan Usaha. Universitas Gadjah Mada.

Widiawaty, M. A. (2019). Mari Mengenal Sains Informasi Geografis. Bandung: Aria Mandiri Group.

Widiawaty, M. A., \& Dede, M. (2018). Pemodelan spasial bahaya dan kerentanan bencana banjir di wilayah timur Kabupaten Cirebon. Jurnal Dialog Penanggulangan Bencana, 9(2), 142-153.

Widiawaty, M. A., Nandi, \& Murtianto, H. (2020). Physical and Social Factors of Shoreline Change in Gebang , Cirebon Regency 1915 - 2019. Journal of Applied Geospatial Information, 4(1), 327-334.

Widyarani, Cahyaningsih, S., Wulan, D. R., \& Sembiring, T. (2019). Water quality assessment around a coalfired power plant in southern coast of Java, Indonesia. Regional Studies in Marine Science, 25, 100463. http://doi.org/10.1016/j.rsma.2018.100463

Xu, Y., Yang, K., Zhou, J., \& Zhao, G. (2020). Coal-Biomass Co-Firing Power Generation Technology : Current Status , Challenges and Policy Implications. Sustainability, 12, 3692.

Yan, C., Zhang, W., Zhang, Z., Liu, Y., Deng, C., \& Nie, N. (2015). Assessment of Water Quality and Identification of Polluted Risky Regions Based on Field Observations \& GIS in the Honghe River Watershed, China. PLOS ONE, 10(3), e0119130. http://doi.org/10.1371/journal.pone.0119130

Yang, Y., Li, C., Wang, N., \& Yang, Z. (2019). Progress and prospects of innovative coal-fired power plants within the energy internet. Global Energy Interconnection, 2(2), 160-179. http://doi.org/10.14171/j.2096-5117.gei.2019.02.008

Young, N. E., Anderson, R. S., Chignell, S. M., Vorster, A. G., Lawrence, R., \& Evangelista, P. H. (2017). A survival guide to Landsat preprocessing. Ecology, 8(4), 920-932. http://doi.org/10.1002/ecy.1730 


\section{Appendixes}

In-situ measurement of TSS and remote sensing (RS) data.

\begin{tabular}{lrrrrr}
\hline Sample & In-situ (mg/l) & \multicolumn{1}{c}{ RS (mg/l) } & Sampel & In-situ (mg/l) & RS (mg/l) \\
\hline TSS-1 & 59 & 52.02 & TSS-5 & 331 & 241.58 \\
TSS-2 & 68 & 91.38 & TSS-6 & 200 & 205.05 \\
TSS-3 & 68 & 33.85 & TSS-7 & 19 & 60.86 \\
TSS-4 & 89 & 83.51 & TSS-8 & 79 & 70.07 \\
\hline
\end{tabular}

In-situ measurement of SST and remote sensing (RS) data.

\begin{tabular}{lrrrrr}
\hline Sample & In-situ $\left({ }^{\circ} \mathrm{C}\right)$ & \multicolumn{1}{c}{$\mathrm{RS}\left({ }^{\circ} \mathrm{C}\right)$} & Sampel & In-situ $\left({ }^{\circ} \mathrm{C}\right)$ & $\mathrm{RS}\left({ }^{\circ} \mathrm{C}\right)$ \\
\hline SST-1 & 34 & 36.98 & SST-14 & 35 & 35.45 \\
SST-2 & 33 & 34.21 & SST-15 & 36 & 34.96 \\
SST-3 & 34 & 35.00 & SST-16 & 35 & 34.47 \\
SST-4 & 35 & 36.16 & SST-17 & 34 & 33.37 \\
SST-5 & 33 & 34.85 & SST-18 & 36 & 34.87 \\
SST-6 & 34 & 35.39 & SST-19 & 35 & 35.24 \\
SST-7 & 34 & 34.77 & SST-20 & 34 & 35.69 \\
SST-8 & 35 & 35.48 & SST-21 & 34 & 34.01 \\
SST-9 & 34 & 33.60 & SST-22 & 35 & 36.35 \\
SST-10 & 35 & 34.87 & SST-23 & 35 & 36.62 \\
SST-11 & 34 & 33.97 & SST-24 & 37 & 35.82 \\
SST-12 & 34 & 34.73 & SST-25 & 34 & 35.64 \\
SST-13 & 36 & 35.74 & SST-26 & 36 & 35.44 \\
\hline
\end{tabular}

In-situ measurement of sea surface salinity (SS-Sal) and remote sensing (RS) data.

\begin{tabular}{lrrrrc}
\hline \multicolumn{1}{c}{ Sample } & In-situ $\left(\mathrm{mg} / \mathrm{m}^{3}\right)$ & \multicolumn{1}{c}{ RS $(\mathrm{psu})$} & Sampel & In-situ $\left(\mathrm{mg} / \mathrm{m}^{3}\right)$ & $\mathrm{RS}(\mathrm{psu})$ \\
\hline Sal-1 & 0.001 & 5858.862946 & Sal-12 & 0.012 & 5856.599713 \\
Sal-2 & 0.002 & 5859.037657 & Sal-13 & 0.013 & 5868.952353 \\
Sal-3 & 0.003 & 5860.415772 & Sal-14 & 0.014 & 5861.491613 \\
Sal-4 & 0.004 & 5861.309229 & Sal-15 & 0.015 & 5851.623825 \\
Sal-5 & 0.005 & 5856.306199 & Sal-16 & 0.016 & 5850.633583 \\
Sal-6 & 0.006 & 5862.870168 & Sal-17 & 0.017 & 5850.769414 \\
Sal-7 & 0.007 & 5866.096681 & Sal-18 & 0.018 & 5856.066840 \\
Sal-8 & 0.008 & 5859.634657 & Sal-19 & 0.019 & 5849.465571 \\
Sal-9 & 0.009 & 5858.520417 & Sal-20 & 0.020 & 5849.886763 \\
Sal-10 & 0.010 & 5863.905229 & Sal-21 & 0.021 & 5857.246186 \\
Sal-11 & 0.011 & 5857.915128 & & & \\
\hline
\end{tabular}

